\title{
Spreading cortical depression blockage of seizures produced by electroconvulsive shock
}

RICHARD W. THOMPSON, WESTERN WASHINGTON STATE COLLEGE JOEL E. MILLER, OHIO UNIVERSITY

Eight rat Ss were given ECS when normal, following surgical preparation for spreading cortical depression (SCD), under Sham SCD or under SCD. All Ss showed full tonic-clonic seizures except when ECS was administered while $S$ was under $S C D$.

Bures \& Buresova (1956) have reported that spreading cortical depression (SCD) decreases the susceptibility of mice to audiogenic seizures. Kesner, O'Kelly, \& Thomas (1965) obtained similar results using SCD and audiogenic susceptible rats. They also found the SCD potentiated the effects of pentobarbital in abolishing audiogenic seizures and counteracted, to some degree, the effects of Metrazol by increasing the latency to seizure. Bures (1959) has also reported that SCD causes an increase in the threshold for electrical stimulation of motor areas of the cortex. The present experiment investigated the effect of SCD on convulsions produced by electroconvulsive shock (ECS). Mefhod

The Ss were eight male albino rats of the SpragueDawley strain, 180-240 days of age. The Ss were maintained on ad lib food and water throughout the experiment.

The ECS was a $50 \mathrm{~mA}$ ac current for $200 \mathrm{msec}$. The ECS was administered through padded alligator clip electrodes, soaked in Ringer's solution, attached to S's pinnae. The $S$ was given ECS while in a plexiglas box 8-1/2 in. square and 9-1/2 in. high.

In preparation for $S C D$, the $S$ was anesthetized with ether, the scalp shaved, and a midline incision made exposing the skull. A $5 \mathrm{~mm}$ hole was made over each parietal cortex, care being taken to avoid damage to the dura. The incision was closed with sutures and the $\mathrm{S}$ was returned to his home cage for approximately $24 \mathrm{~h}$.

To Induce SCD or sham SCD, the S was lightly anesthetized with ether, the incision reopened, and the wound cleansed with Ringer's solution. For SCD, a $4 \mathrm{~mm}$ circle of filter paper soaked in a $25 \%$ solution of $\mathrm{KCl}$ was placed on the dura in each hole. For Sham SCD, the fulter paper was soaked in Ringer's solution. After placement of the filter papers, the incision was reclosed and the $S$ returned to his home cage. The $S$ was anesthetized for approximately $10 \mathrm{~min}$. The ECS treatment was given $30 \mathrm{~min}$ after application of the filter papers.

For ECS testing, the Ss were divided into two groups of four. All Ss in Group 1 received ECS on Day 1 and 1 h later were prepared surgically for SCD. On Day 2, two Ss received Sham SCD treatment, the other two
Ss received SCD treatment. All Ss received ECS 30 min after application of the filter papers. On Day 3 the $S$ receiving Sham SCD on Day 2 were given SCD treatment and the Ss receiving SCD treatment on Day 2 received Sham SCD. All Ss were again given ECS.

Group 2 Ss were all surgically prepared on Day 1. On Day 2 all Ss were given ECS but neither Sham SCD nor SCD. On Day 3 two Ss were given ECS under Sham SCD and two Ss were given ECS under SCD. On Day 4 the cortical conditions were reversed for these Ss and they were again given ECS.

\section{Results and Discussion}

All Ss under normal or Sham SCD conditions showed full tonic-clonic seizures when given ECS; no S under SCD showed a seizure when given ECS. The response of Ss under SCD to the ECS was a violent jump, but no convulsion, coma, or running fit.

As was suggested by Bures (1959), the threshold for electrical stimulation of the motor response seems to be greatly increased. These data are also consistent with those of Bures \& Buresova (1956) and Kesner, O'Kelley, \& Thomas (1965) in their findings that SCD reduces susceptibllity to audiogenic seizures.

The data also suggest that the convulsion produced by ECS is produced mainly through cortical areas since SCD has its main effect in the depression of cortical activity. If, during ECS produced convulsions, some subcortical areas are functional, this could explain the gradual acquisition of a response in animals convulsed after each training trial; at least part of the engram is being stored subcortically. The sparing of subcortical areas during an ECS convulsion could also explain the paradoxical finding that an animal will learn to avoid the place where an ECS is given even though the ECS is supposed to produce retrograde amnesia for events just prior to the ECS (Delprato \& Thompson, 1965). Again, the engram for the averm sive effect of the ECS could be stored subcortically.

\section{References}

BURES, J. Reversible decortication and behavior. In M. A. Brazier (Ed.), Conference on the central nervous system and behavior. New York: Josiah Macy, Jr. Foundation, 1959. Pp. 207-248.

BURES, J., \& BURESOVA, O. The influence of reflex acoustic epilepsy and reflex inhibition ("animal hypnosis") by spreading EEG depression. Physiol Bohemsol, 1956, 5, 395-400.

DELPRATO, D. J., \& THOMPSON, R. W. Amnesic and aversive effects of electroconvulsive shock. Psychol Rep., 1965, 16, 561-565.

KESNER, R. P., O'KELLEY, L. 1., \& THOMAS, G. J. Effects of cortical spreading depression and drugs upon audiogenic seizures in rats. $J$. comp. physiol Psychol, 1965, 59, 280-282. 